\title{
Origin and evolution of Mytilus mussel satellite DNAs
}

\author{
A. Martínez-Lage*, F. Rodríguez-Fariña, A. González-Tizón, and J. Méndez \\ Departamento de Biología Celular y Molecular, Facultad de Ciencias, Universidade da Coruña, A Zapateira s/n, \\ 15071 La Coruña, Spain
}

Genome, volume 48, issue 2, pages 247-256, april 2005

Received 26 june 2004, accepted 23 november 2004, first published 18 march 2005

\section{How to cite:}

Origin and evolution of Mytilus mussel satellite DNAs. A. Martínez-Lage, F. Rodríguez-Fariña, A. González-Tizón, and J. Méndez, Genome, 48(2), 2005, 247-256. https://doi.org/10.1139/g04-115

\begin{abstract}
A phylogenetic reconstruction based on the amplification of 3 satellite DNAs (stDNAs) was carried out in 1 crustacean species and 15 bivalve species of the subclass Pteriomorphia (10, subfamily Mytilinae; 1, subfamily Litophaginae; 1, subfamily Modiolinae, all belonging to family Mytilidae; 1, family Arcidae; and 2, family Pectinidae). The sequences obtained showed motifs with high similarity to those of A and B boxes of tRNA promoter regions. Dot-blot hybridizations revealed that the 3 stDNAs are present mainly in high copy numbers for each species of the genus Mytilus, whereas for the other species they appear in low copy numbers. Maximum-parsimony trees evidenced a tendency to group Mytilus clones together, and species containing these sequences as a single copy were distributed among the different mytilids. Finally, the possible origin and evolution of these stDNAs is discussed.
\end{abstract}

Keywords: bivalves, Pteriomorphia, satellite DNA, phylogeny, dot-blot.

\section{Introduction}

Satellite DNA sequences are highly tandem repeated monomers mainly located at the centromeres or telomeres, or, less frequently, in interstitial chromosome regions. These repeats show high variability in sequence, frequency, and chromosomal distribution, even among closely related species (Miklos 1985; Charlesworth et al. 1994).

Usually, satellite DNAs (stDNAs) show rapid evolution among species, so that in short periods of time new families of satellite DNAs can arise or disappear (Miklos 1985). There are species-specific stDNAs, as, for example, in primates (Fanning et al. 1989) or in orthoptera (Bachmann et al. 1994), and sex-specific stDNAs, as in those from bats (Van den Busche et al. 1993) or horses (Wijers et al. 1993), and both types have a relatively recent evolutionary origin (Singer 1982). However, other stDNAs show a high degree of sequence conservation, and they are present in all the members of the same family, as observed in Cebidae (Fanning et al. 1993) or in Cetacea (Arnason 1990). These satellite sequences are widely spread across distantly related species, as, for example, the alpha-centromeric satellites of primates (Willard 1991; Fanning et al. 1993).

To explain the evolution of stDNA, Salser et al. (1976) proposed that related species share a "library" of conserved satellite sequences, some of which could be amplified, and then a larger stDNA is generated for a particular species. This model is supported by Meštrovi et al. (1998), who analyzed 4 congeneric species of 
Coleoptera, each containing a different single stDNA. They proposed that these differences occur as a result of a sudden amplification of a library of conserved stDNA, its spread by a mechanism of unequal crossing over, and its fixation within some individuals in a population.

On the other hand, Nijman and Lenstra (2001) proposed a model of "the life history of satellite DNAs", which postulates that homogeneity of interacting repeating units is "both cause and consequence of the rapid turnover of stDNA". In the first phase, the amplification of homogeneous repeating units would occur, and, in the second phase, mutational events would give rise to variants that amplify independently. Later, recombination would prevent homogenization due to the spreading of 1 of the variants, and the satellite would eventually be outcompeted by another, more homogeneous tandem repeat sequence.

Studies on the evolution of stDNA in molluscs are scarce. Only Muchmore et al. (1998) in 5 species of Eastern Pacific abalone (genus Haliotis) and Martínez-Lage et al. (2002) in 4 Mytilus species carried out evolutionary studies on stDNAs. In the analysis performed by Martínez-Lage et al. (2002), 3 different types of stDNAs in M. edulis, M. galloprovincialis, M. trossulus, and M. californianus were used. The sequencing results revealed that $M$. californianus is the most divergent species with respect to the other 3 . Chromosome in situ hybridization showed a different organization and distribution of the 3 satellites in each species, and the genome proportion of each type of stDNA also varied.

The central aim of the present work is to perform a molecular analysis of the 3 stDNAs used in our previous work (Martínez-Lage et al. 2002) to investigate the evolution of these sequences in the subfamily Mytilinae and analyze its possible origin and differentiation; as well, we discuss the model of "the life history of satellite DNAs" proposed by Nijman and Lenstra (2001). Specific primers were used to amplify genomic DNA from 15 bivalve and 1 crustacean species. The sequences obtained showed high similarity (with the exception of satellite 1 of M. californianus), although dot-blot analysis revealed that only the Mytilus species has a high copy number, and the rest of the species have a low copy number.

\section{Material and methods}

\section{$\underline{\text { PCR amplifications and sequencing }}$}

The specimens analyzed were collected from the localities shown in Table 1. Clones of M. edulis, M. galloprovincialis, $M$. trossulus, and $M$. californianus were previously described by Martínez-Lage et al. (2002). DNA was obtained from adductor muscles or mantles following the protocol described in Rice and Bird (1990).

PCR amplifications from template genomic DNA were performed in a final volume of $25 \mu \mathrm{L}(1 \mathrm{ng} / \mu \mathrm{L})$ using he following primers at $0.2 \mathrm{mmol} / \mathrm{L}$ an d1Uof Taq DNA polymerase (Roche Molecular Biochemicals, Mannheim, Germany): S1F, 5'-TTCCATATCAACCACACATT-3', and S1B, 5'AATACGTAAATGGGCAACTT-3', for type 1 stDNA; S2F, 5'-ACCAAAACTCCCAAAATCAA-3', and S2B, 5'-CCCAACAGT-TTAGGAATTAG-3', for type 2 stDNA; and S3F, 5'GTCACCCTACCGCTACTTTG-3', and S3B, 5'-CATCCACCTTCTTTCGTTCA-3' , for type 3 stDNA. The PCR amplification profile for type 1 stDNA consisted of 1 initial denaturation cycle of 3 min at $94{ }^{\circ} \mathrm{C}$, followed by 35 amplification cycles of $1 \mathrm{~min}$ at $94{ }^{\circ} \mathrm{C}$ for denaturation, $30 \mathrm{~s}$ at $45{ }^{\circ} \mathrm{C}\left(55\right.$ and $58{ }^{\circ} \mathrm{C}$ for types 2 and 3 stDNA, respectively) for annealing, and $45 \mathrm{~s}$ at $72{ }^{\circ} \mathrm{C}$ for extension. A final extension cycle was performed at $72{ }^{\circ} \mathrm{C}$ for $5 \mathrm{~min}$. The fragments obtained by PCR were ligated into the plasmid pGEM-T Easy Vector System (Promega Corporation, Madison, Wis.) and automatically sequenced using an ALFexpress instrument (Amersham Pharmacia Biotech, Uppsala, Sweden). 
Table 1. Taxa used in the molecular analysis of 3 satellite DNAs (stDNA)

\begin{tabular}{|c|c|c|c|c|}
\hline \multirow[b]{2}{*}{ Taxon } & \multirow[b]{2}{*}{ Collection site } & \multicolumn{3}{|c|}{ EMBL-GenBank-DDBJ accession number* } \\
\hline & & Type 1 stDNA & Type 2 stDNA & Type 3 stDNA \\
\hline \multicolumn{5}{|l|}{ Class Bivalvia } \\
\hline \multicolumn{5}{|l|}{ Subclass Pteriomorphia } \\
\hline \multicolumn{5}{|l|}{ Family Arcidae } \\
\hline Arca noae & Benicarló, Valencia, Spain & AJ549340 & AJ549257 & AJ549276 \\
\hline \multicolumn{5}{|l|}{ Family Mytilidae } \\
\hline \multicolumn{5}{|l|}{ Subfamily Mytilinae } \\
\hline Mytilus edulis & Yerseke, Holland & AJ420289-AJ420291 & AJ420303-AJ420305 & AJ420758-AJ420759 \\
\hline Mytilus chilensis & Puerto Aguirre, Chile & AJ549331-AJ54933 & AJ549251-AJ549253 & AJ549267-AJ549269 \\
\hline Mytilus galloprovincialis & Balcobo, La Coruña, Spain & AJ420292-AJ420296 & AJ420306-AJ420308 & AJ420760-AJ420762 \\
\hline Mytilus trossulus & $\begin{array}{l}\text { Esquimalt Lagoon, Vancouver Island, } \\
\text { B.C., Canada }\end{array}$ & AJ420297-AJ42099 & AJ420309-AJ420311 & AJ420763-AJ420765 \\
\hline Mytilus californianus & $\begin{array}{l}\text { Point no Point, Vancouver Island, B.C., } \\
\text { Canada }\end{array}$ & AJ420300-AJ420302 & AJ420312 & AJ420766-AJ420768 \\
\hline Mytilus coruscus & Otsuchi Bay, Japan & AJ549334-AJ549338 & AJ549254-AJ549256 & AJ549270-AJ549271 \\
\hline Perna canaliculus & Golden Bay, New Zealand & AJ549347 & AJ549263 & AJ549275 \\
\hline Aulacomya ater & Callao, Peru & AJ549345 & AJ549260-AJ549261 & AJ549274 \\
\hline Choromytilus chorus & Concepción, Chile & AJ549346 & AJ549262 & AJ549273 \\
\hline Septifer virgatus & Otsuchi Bay, Japan & AJ549342-AJ549344 & AJ549259 & AJ549277 \\
\hline \multicolumn{5}{|l|}{ Subfamily Lithophaginae } \\
\hline Lithophaga lithophaga & Benicarló, Valencia, Spain & AJ549341 & AJ549258 & AJ549278 \\
\hline \multicolumn{5}{|l|}{ Subfamily Modiolinae } \\
\hline Geukensia demissa & St. Mary's River, Md., USA & AJ549339 & N.A. & AJ549272 \\
\hline \multicolumn{5}{|l|}{ Family Pectinidae } \\
\hline Pecten maximus & O Grove, Pontevedra, Spain & N.A. & AJ549264-AJ549265 & AJ549281-AJ549282 \\
\hline Mimachlamys varia & Málaga Bay, Spain & N.A. & N.A. & AJ549279-AJ549280 \\
\hline \multicolumn{5}{|l|}{ Class Crustacea } \\
\hline Pollicipes cornucopia & Cedeira, La Coruña, Spain & N.A. & AJ549266 & N.A. \\
\hline
\end{tabular}


Consensus sequencing was performed by using the internal repeats of satellite DNA sequences and the computer program CLUSTAL X (Thompson et al. 1997). Maximum-parsimony trees were constructed by close neighbor interchange search. Resolution of internal nodes was performed using 500 bootstrap iterations with random replacement (Felsenstein 1985). Phylogenetic and molecular evolutionary analyses were conducted using version 2.1 MEGA software (Kumar et al. 2001). Motifs of the internal promoters of tRNA (A and B boxes) were also analyzed using CLUSTAL X and MEGA software.

\section{Dot-blot hybridization}

Mussel populations used to estimate the copy number of the target DNA sequences in diploid genomes were M. edulis from Yerseke (Holland) and Prince Edward Island; M. galloprovincialis from Ria de Arousa, Balcobo, and Ebro Delta (all on Spanish coasts); M. trossulus from Öland Island (Sweden), Esquimalt Lagoon (Vancouver Island, B.C.), and Bedford Basin (Newfoundland and Labrador); M. chilensis from Puerto Aguirre (Chile); M. coruscus from Otsuchi Bay (Japan), and M. californianus from Point No Point (Vancouver Island, B.C.).

Solutions containing denatured genomic DNA (200, 100, 50, and 25 ng, except for Esquimalt Lagoon mussels that were $64,32,16$, and $8 \mathrm{ng})$ and denatured $M$. galloprovincialis repetitive DNA fragments $(0.8$, $0.4,0.2$, and $0 \mathrm{ng}$ ) were vacuum-blotted onto nylon membranes in a Bio-Rad dot-blotting apparatus. Astringency washes were performed in $0.2 \times \mathrm{SSC}(1 \times \mathrm{SSC}: 0.15 \mathrm{~mol} \mathrm{NaCl} / \mathrm{L}$ plus $0.015 \mathrm{~mol}$ sodium citrate/L) $1 \% \mathrm{SDS}$ at $50{ }^{\circ} \mathrm{C}$. Hybridization was detected using the Dig Luminescent Detection kit for nucleic acids (Roche Molecular Biochemicals) following the manufacturer's instructions. Hybridization signals were quantified as in Martínez-Lage et al. (2003). The copy numbers of Mytilus spp. repetitive sequences were calculated from a linear plot made from dilutions of $\mathrm{M}$. edulis repetitive DNA fragments. The haploid DNA contents of M. edulis and M. galloprovincialis were 1.71 and $1.92 \mathrm{pg}$, respectively (Rodríguez-Juiz et al. 1996), $1.90 \mathrm{pg}$ for $M$. coruscus (Ieyama et al. 1994), and 1.51 and $1.61 \mathrm{pg}$ for M. trossulus and $M$. californianus, respectively (González-Tizón et al. 2000). For $M$. chilensis the haploid DNA content of M. edulis was used, because many investigators consider that M. chilensis is a subspecies of M. edulis.

The hybridization control for low copy number was a digoxigenin-labelled probe obtained from a PLII fragment (Heath et al. 1995). This fragment is $\sim 425$ bp in length and has a copy number ranging from 4 to 13, depending on the mussel species (Heath and Hilbish 1998; Rodríguez-Fariña 2001). To confirm that a similar DNA concentration was used in each dot-blot, a final hybridization was carried out with an rDNA probe (18S-5.8S-28S) containing $~ 750$ copies per haploid genome.

\section{Results}

DNA amplifications with the primers previously designed by Martínez-Lage et al. (2002) yielded fragments in the ranges $170-175 \mathrm{bp}$ for type 1 stDNA, 159-162 bp for type 2, and 88-89 bp to 164-167 bp for type 3 . Table 1 shows the taxa used in this study. One clone from each individual was sequenced, although in the non-Mytilus species at least 3 clones were sequenced from each individual.

In addition, DNA amplifications were carried out with these primers in other bivalve species (data not shown): Ostrea edulis and Crassostrea angulate (family Ostreidae), Chlamys opercularis (family Pectinidae), Pinna pectinata (family Pinnidae), Cerastoderma edule (family Cardiidae), Donax trunculus (family Donacidae), Dosinia lupinus, Tapes decussatus, Venerupis rhomboides, and Venerupis pullastra (family Veneridae), Ensis arcuatus and Ensis silique (family Pharidae), and Solen marginatus (family 
Solenidae). However, amplification fragments were not obtained in all of them. DNA amplifications from Drosophila melanogaster and humans were used as negative controls.

Alignments of the nucleotide sequences from type 1 stDNA (Fig. 1a) reveal similarity values above 86.70\%, with the exception of $M$. californianus which shows about $37.00 \%$. Comparison between M. coruscus (clone pCOB 105) and Aulacomya ater (pAUL 101), and between Arca noae (pARC 101) and Lithophaga lithophaga (pLIT 101) reveals that these species are highly similar. For type 2 stDNA (Fig. 1b) A. ater (pAUL 202) and Perna canaliculus (pPER 201) display the highest sequence similarity, and the other species exhibit values above $84.50 \%$, with the exception of $M$. californianus (values close to $75.00 \%$ ).

a)
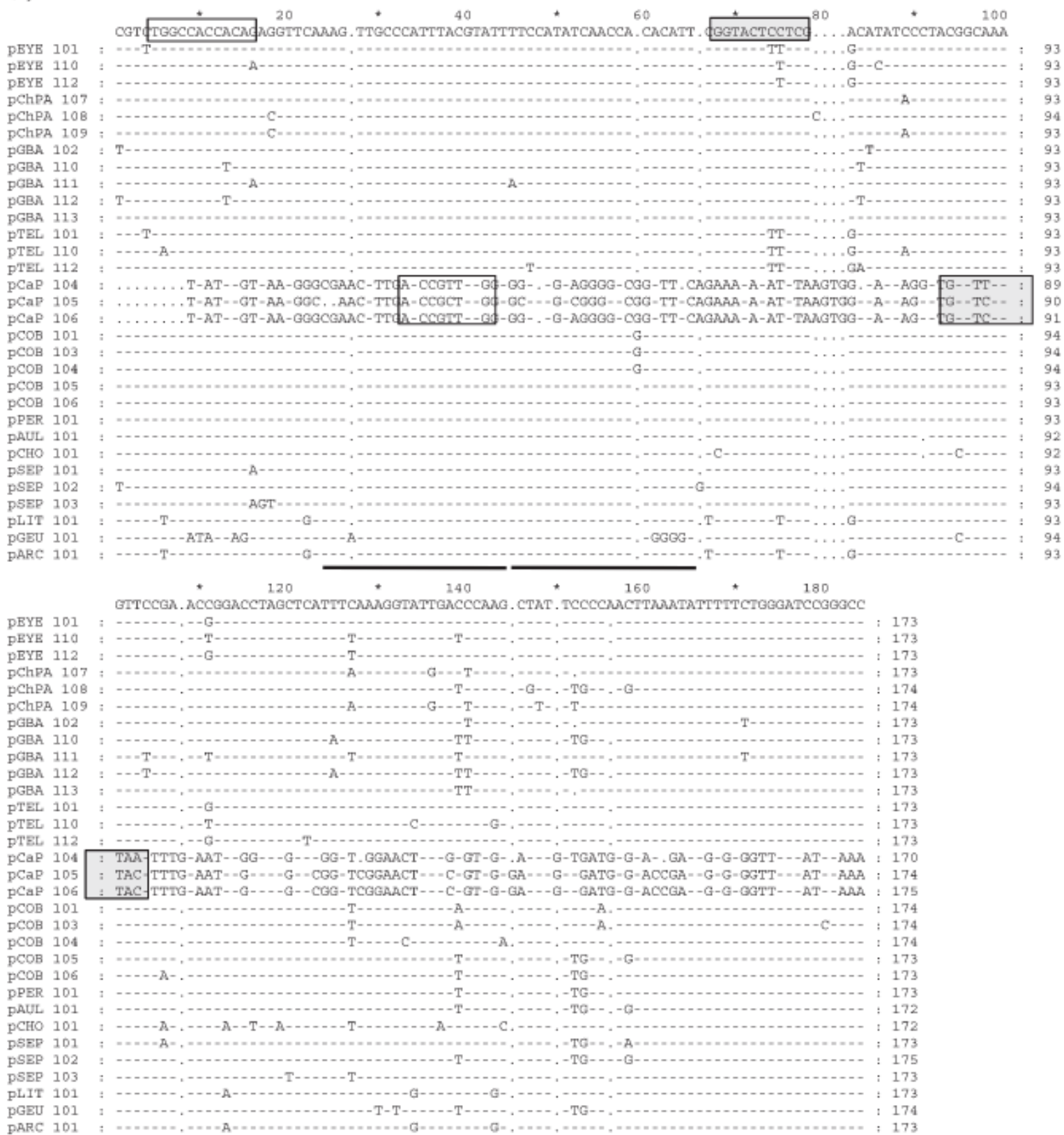

Figure 1. Nucleotide sequences of a) DNA type 1, b) DNA type 2, and c) DNA type 3. Monomers derived from the same cloned fragments are indicated as suffixes: EYE as Mytilus edulis, ChPA as M. chilensis ,GBAas M. galloprovincialis, TEL as M. trossulus, CaP as M. californianus, COB as M. coruscus, PER as Perna canaliculus, AUL as Aulacomya ater,CHOas Choromytilus chorus, SEP as Septifer virgatus, LITas Lithophaga lithophaga, GEU as Geukensia demissa, ARC as Arca noae, POL as Pollicipes cornucopia, PEC as Pecten maximus, and CHL as M. varia. Only nucleotides divergent from the top sequences are indicated in particular monomers, and gaps are shown with dots. 
White and grey boxes indicate similarity with A box (5 '-TRGCNNAGY*GG-3' ) and B box (5'-GGTTCGANTCC-3'), respectively, internal promoters of tRNA (Geiduschek and Tocchini-Valentini 1988). Primer binding sites are underlined.

b)
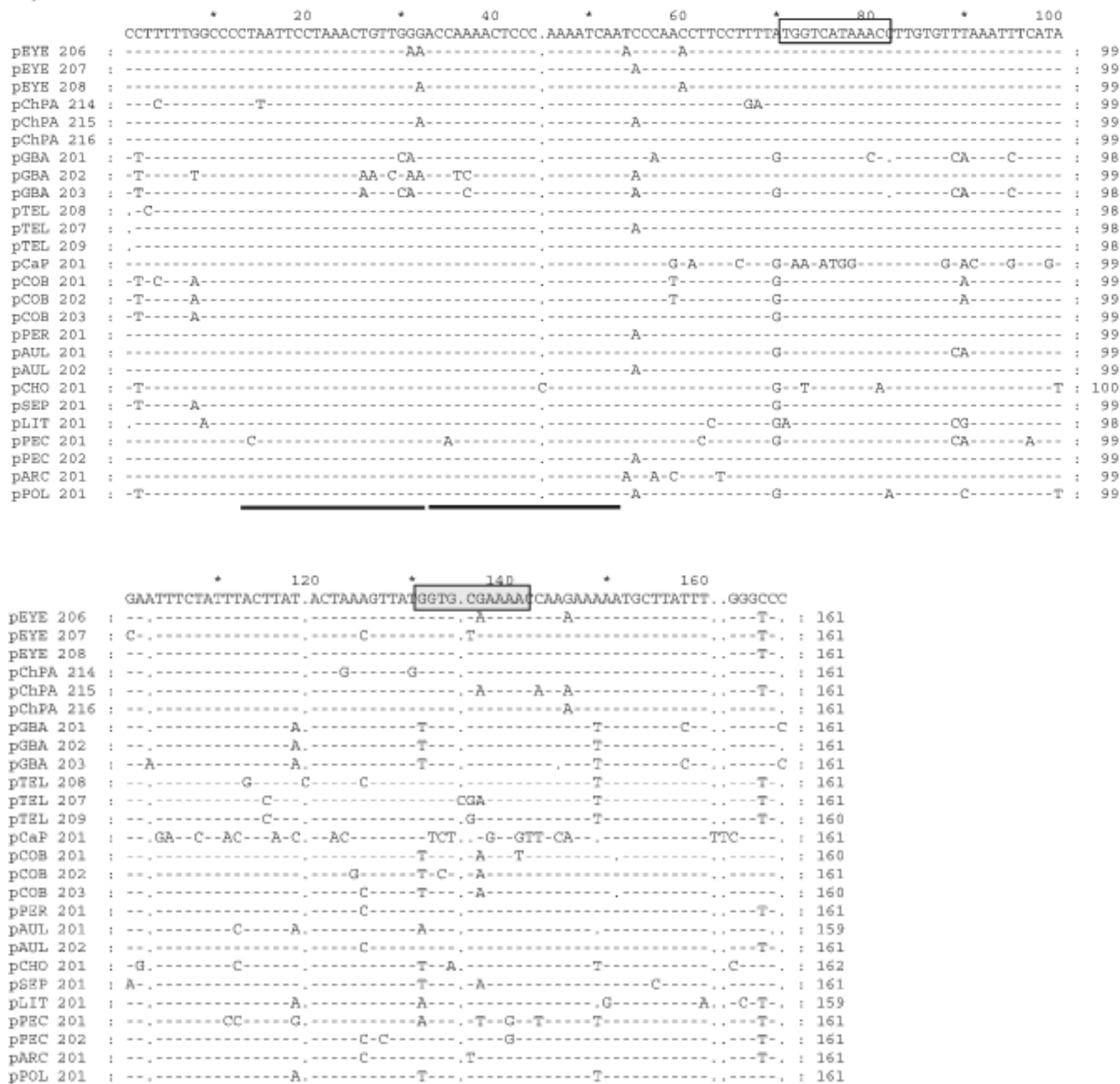

Figure $1 c$ shows that Septifer virgatus (pSEP 301) and L. litophaga (pLIT301) are the most divergent among the species, displaying a similarity value of $60.00 \%$. The rest of the species show similarity values above $84.50 \%$. M. californianus is less divergent for satellite type 3 than for satellite types 1 and 2 .

The sequences obtained have been aligned, showing the motifs that display a certain similarity with those of A box and B box of promoter regions of tRNAs. In M. californianus, this motif is different from that in the rest of the species (Fig. 1 a). Similarity values are about $63.64 \%$ in A box and B box of type 1 stDNA, increasing to $72.73 \%$ for A box in $M$. californianus. In the case of type 2 stDNA, the similarity value for A box is $45.46 \%$ and for B box is $72.73 \%$. In type 3 stDNA, similarity values are $81.82 \%$ and $54.55 \%$ for A box and B box, respectively. Finally, A and B boxes in S. virgatus and L. litophaga do not show similarity with any of the other species. 


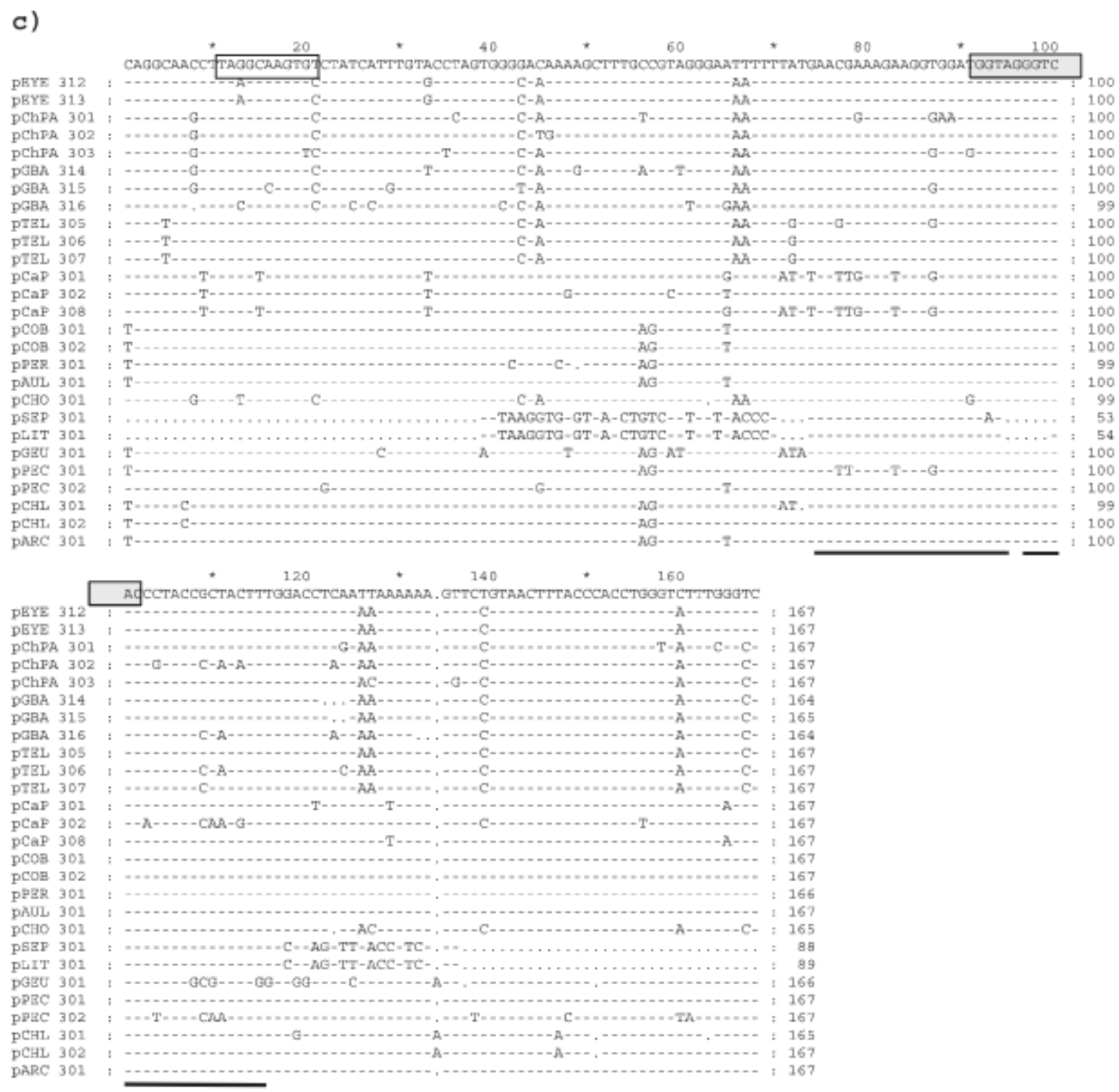

Results from dot-blot hybridizations (Fig. 2) reveal that these stDNA sequences are present in high copy numbers for each species of the genus Mytilus (M. edulis, M. galloprovincialis, M. trossulus, M. chilensis, M. coruscus, and $M$. californianus), whereas for the other species they are single copy sequences because fewer than 10 copies are present. Table 2 shows the copy number and proportion of each satellite DNA in each population analyzed. For copy number, a notable difference exists between M. californianus and the other species used. Another remarkable finding is the high copy number and proportion of type 3 stDNA in M. trossulus species.

The pairwise comparison of Kimura 2-parameter distance and transition/transversion (ts/tv) (data not shown; provided upon request) ratios for type 1 stDNA showed that distance values tend to be lower than 0.10 ; for Geukensia demissa, values ranged from 0.09 to 0.15 , and $M$. californianus clones showed the highest distance values (1.22-2.17). On the other hand, transitions are more abundant than transversions, as evidenced by ts/tv ratios greater than 1.0. For type 2 stDNA, distance values ranged from 0.01 to 0.36 , again M. californianus showing the highest values. Like type 1 stDNA, type 2 shows ts/tv values above 1.0. For type 3 stDNA, distance values ranged from 0.01 to 0.49 , those corresponding to $S$. virgatus and L. litophaga being the highest. With a few exceptions, ts/tv ratios were less than 1.0. 


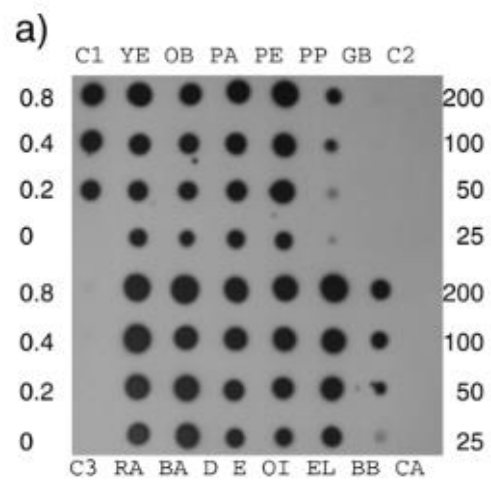

b)

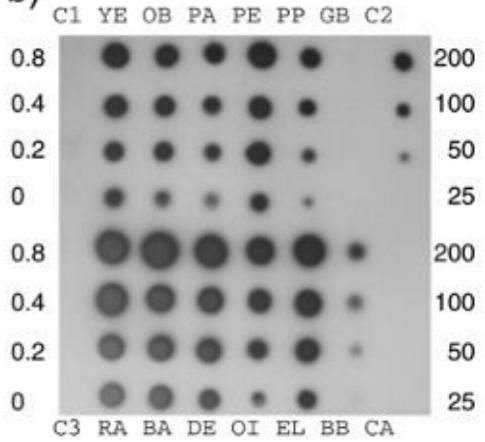

c)

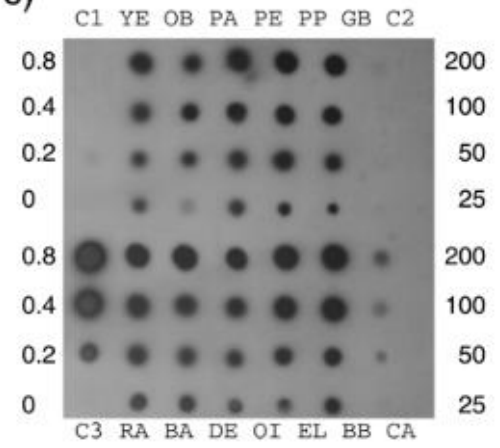

Figure 2. Dot-blot hybridizations from total genomic DNAs: Mytilus edulis from Yerseke (YE) and Prince Edward Island (PE); M. coruscus from Otsuchi Bay (OB); M. chilensis from Puerto Aguirre (PA); M. californianus from Point No Point (PP); Perna canaliculus from Golden Bay (GB); M. galloprovincialis from Ria de Arousa (RA), Balcobo (BA), and Delta del Ebro (DE); M. trossulus from Öland Island (OI), Esquimalt Lagoon (EL), and Bedford Basin (BB); and Aulacomya ater from El Callao (CA). C1, C2, and C3 correspond to M. edulis satellite DNA fragments, types 1, 2, and 3, respectively. Hybridizations with (a) type 1 stDNA, (b) type 2 stDNA, and (c) type 3 stDNA. Amounts of blotted DNA are 200, 100, 50, and $25 \mathrm{ng}$ for genomic DNAs (except for Esquimalt Lagoon, which are 64, 32, 16, and $8 \mathrm{ng}$ ); for repeated DNA controls, $0.8,0.4,0.2$, and $0 \mathrm{ng}$.

As shown in the maximum-parsimony trees (Fig. 3), clones containing stDNA sequences (genus Mytilus) tend to group together, whereas clones containing these sequences as single copy are distributed among the different mytilids. The topology of the tree obtained for type 1 stDNA (Fig. $2 a$ ) shows a cluster containing all the $M$. californianus clones and another cluster with $M$. coruscus clones. $M$. chilensis and $M$. galloprovincialis cluster together (with the exception of 1 clone for each species), as do $M$. edulis and $M$. trossulus. The 3 clones of $S$. virgatus are dispersed among the other species. The topology for type 2 stDNA (Fig. 2b) reveals that genus Mytilus clones do not group together, with the exception of M. coruscus. For type 3 stDNA only $M$. coruscus clones group together in the same cluster with $A$. ater and $A$. noae ; the other mytilid clones group separately.

Table 2. Copy number and proportion for the different satellite DNAs (stDNA) in 11 Mytilus mussel populations.

\begin{tabular}{|c|c|c|c|c|c|c|}
\hline \multirow{3}{*}{ M. edulis } & \multicolumn{6}{|c|}{ Copy number and $\%$ genomic content } \\
\hline & \multicolumn{2}{|c|}{ Type 1 stDNA } & \multicolumn{2}{|c|}{ Type 2 stDNA } & \multicolumn{2}{|c|}{ Type 3 stDNA } \\
\hline & & & & & & \\
\hline Yerseke & 45000 & $0.46 \%$ & 140000 & $1.31 \%$ & 1100 & $0.01 \%$ \\
\hline Prince Edward Island & 53000 & $0.54 \%$ & 120000 & $1.11 \%$ & 1400 & $0.01 \%$ \\
\hline \multicolumn{7}{|l|}{ M. galloprovincialis } \\
\hline Ría de Arousa & 69000 & $0.63 \%$ & 150000 & $1.27 \%$ & 4400 & $0.04 \%$ \\
\hline Balcobo & 79000 & $0.73 \%$ & 200000 & $1.66 \%$ & 3500 & $0.03 \%$ \\
\hline Delta del Ebro & 71000 & $0.65 \%$ & 180000 & $1.55 \%$ & 2800 & $0.03 \%$ \\
\hline \multicolumn{7}{|l|}{ M. trossulus } \\
\hline Oland Island & 60000 & $0.70 \%$ & 110000 & $1.13 \%$ & 7400 & $0.08 \%$ \\
\hline Esquimalt Lagoon & 70000 & $0.79 \%$ & 140000 & $1.51 \%$ & 11000 & $0.12 \%$ \\
\hline Bedford Bassin & 60000 & $0.71 \%$ & 130000 & $1.36 \%$ & 8000 & $0.09 \%$ \\
\hline \multicolumn{7}{|l|}{ M. chilensis } \\
\hline Puerto Aguirre & 37000 & $0.38 \%$ & 110000 & $1.04 \%$ & 1100 & $0.01 \%$ \\
\hline \multicolumn{7}{|l|}{ M. coruscus } \\
\hline Otsuchi Bay & 35000 & $0.37 \%$ & 110000 & $1.08 \%$ & 1600 & $0.02 \%$ \\
\hline \multicolumn{7}{|l|}{ M. californianus } \\
\hline Point No Point & 8500 & $0.10 \%$ & 80000 & $0.85 \%$ & 10000 & $0.11 \%$ \\
\hline
\end{tabular}




\section{Discussion}

The previous characterization of 3 satellite DNAs in the mussel species M. edulis, M. galloprovincialis, M. trossulus, and M. californianus (Martínez-Lage et al. 2002) revealed that monomeric lengths were $171 \mathrm{bp}$ for type 1 satellite DNA, $161 \mathrm{bp}$ for type 2 satellite DNA, and $167 \mathrm{bp}$ for type 3 . The determination of the genomic contents of these repetitive sequences showed that type 2 satellite DNA was the most abundant of the 4 mussel species, and type 3 showed the lowest content. Fluorescent in situ hybridization revealed a random distribution of these repetitive sequences into several small clusters dispersed along the chromosomes.

In the present study, these repetitive DNA sequences were analyzed in other Mytilus species and in bivalve species closely related to the genus Mytilus (Table 1). The results reveal that monomeric lengths and sequence similarities are very like those reported for the 4 Mytilus mussels previously analyzed (MartínezLage et al. 2002) and that single-point mutations are the major contributors to divergence among them. However, there is interspecific variability in copy number, so that only the species belonging to the genus Mytilus present these sequences as satellite DNAs (high copy number), whereas in the rest of the species they appear as single copy or as low copy number. DNA from D. melanogaster and humans was used as a negative control because the DNA from the crustacean Pollicipes cornucopia (initially selected as a negative control) was amplified with type 2 stDNA. On the other hand, the analyses of different populations of M. edulis, M. galloprovincialis, and M. trossulus showed very slight differences in copy number.

Repetitive sequences can be classified according to the genetic mechanism by which they originate. DNA duplications create tandemly repeated sequences, whereas retrotransposition events generate dispersed elements (Ohshima et al. 1993). As observed in the sequence alignments (Fig. 1), these repetitive sequences show a region similar to those in A and B tRNA boxes, which initially suggests that they could be tRNAderived pseudogenes. As Oshima et al. (1993) and Ohshima and Okada (1994) suggested, these types of sequence are usually derived by retroposition. Under the "selfish" DNA hypothesis, repetitive sequences would accumulate in heterochromatin because these regions do not contain genes, and, subsequently, they are less likely to be deleterious, although accumulation of highly repetitive sequences is expected to occur only in regions where there is very low recombination and weak selective constraints on array length (Charlesworth et al. 1986, 1994; Stephan 1989). Under the same hypothesis, this process would occur by transposition and subsequent increase in their copy number. However, the possibility of horizontal transfer of satellite repeats among species is highly improbable because of the distribution of these sequences among taxonomically related species and the absence of data confirming the occurrence of the same satellite DNA in phylogenetically unrelated groups (Meštrovi et al. 1998). Our results agree with the library hypothesis proposed by Nijman and Lenstra (2001). These authors suggested that related species share a library of conserved satellite sequences, some of which could be amplified, creating a larger satellite DNA in a particular species. So, these sequences would have spread to constitute bigger satellite DNAs in the genus Mytilus species, but in the rest of the "non-Mytilus" species would have remained as a single copy or low copy number. Probably, the expansion of these 3 satellite DNAs could have occurred in the recent Jurassic, 150 million years ago, when the genus Mytilus emerged (Cox et al. 1969).

The high sequence similarity displayed among the 3 types of sequence (except for type 1 stDNA in $M$. californianus) suggests that types 1,2 , and 3 repetitive sequences are in the initial phase of the model proposed by Nijman and Lenstra (2001). This model is known as "life history of satellites" and it postulates the existence of 3 phases in the evolution of satellite DNAs. During the initial phase, interactions of homogeneous repeating units cause rapid expansions and contractions, leading to saltatory fluctuations in the copy number. Perhaps, in M. californianus, type 1 stDNA would be in the second phase of this model, when mutations and recombination are acting to lead to divergence of sequence variants. Then, taking into account transition/transversion values, as in Kimura's 2-parameter model, Li (1997) proposed that when a sequence is recent $(\leq 50 \mathrm{~m} . \mathrm{y}$. old $)$ ts/tv ratios are above 1.0 . When the evolutionary time is approximately 50 
million years ago, the ts/tv ratios are 1.0 or close to 1.0 , and when it is more than 200 million years these ratios are 0.5. According to Li (1997), type 3 stDNA in M. californianus would be older than types 1 and 2, but, according to the results of Salser et al. (2001), the oldest would be type 1 stDNA. There are 2 possibilities to explain the origin of these 3 types of satellite DNAs: (i) that each occurred at different evolutionary times, or ((ii) that the 3originated at the same time but by different evolutionary mechanisms (gene conversion, recombination, mutation), these being faster or more active in type 1 stDNA than in types 2 and 3. The parsimony trees obtained in this analysis (Fig. 3) show the divergence among clones of different species, and also the tendency of clones of the same Mytilus species to group in a single cluster. This does not always occur, perhaps because stDNA clusters are dispersed throughout the genomes of these species.
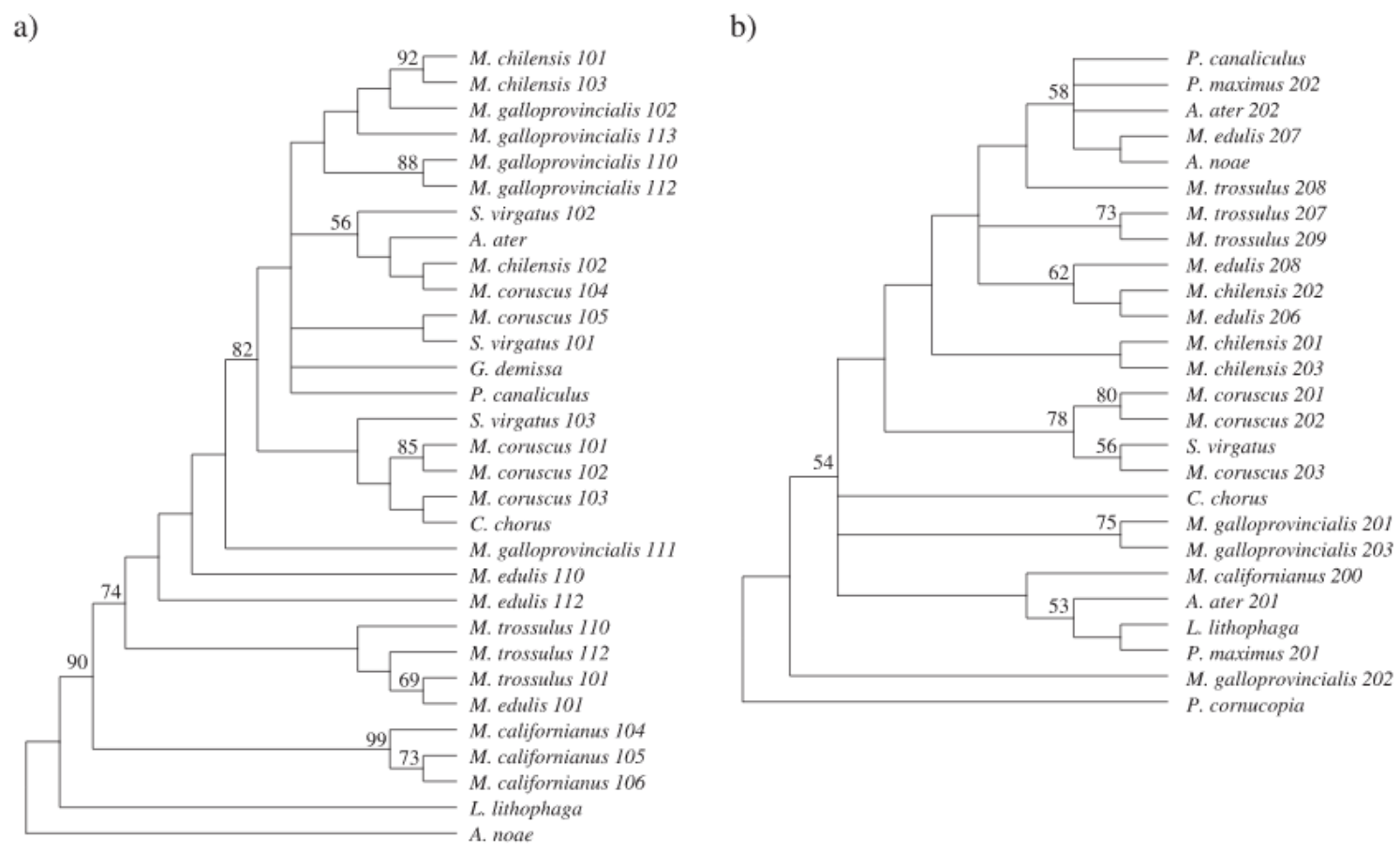

Figure 3. Maximum-parsimony bootstrap (500 replicates) consensus trees for (a) DNA type 1, (b) DNAtype2, and (c) DNA type 3. Bootstrap values over 50\% are shown above branches. The numbers at the end of the branches refer to the number of the clone analyzed.

Different studies were conducted to analyze phylogenetic relations among members of the Mytilinae subfamily using nuclear ribosomal DNA sequences (Kenchington et al. 1995; Steiner and Müller 1996; Winnepenninckx et al. 1996; Adamkewicz et al. 1997; Distel 2000) or mitochondrial DNA (Edwards and Skibinski 1987; Geller et al. 1993; Hilbish et al. 2000). None of these analyses grouped M. edulis clones and M. galloprovincialis clones separately, however. Our analysis with stDNAs shows both species in different clusters (Fig. 3). In the case of M. trossulus clones, phylogenies obtained from mitochondrial DNA sequences show them grouping in well-defined clusters (Geller et al. 1993; Hilbish et al. 2000), whereas those obtained from nuclear ribosomal DNA appear in an ambiguous position (Kenchington et al. 1995; Distel 2000). In all the studies performed until now, M. californianus has proved to be the most divergent species (Kenchington et al. 1995; Distel 2000; Hilbish et al. 2000; Eirín-López et al. 2002; present work). Finally, allozyme analysis has shown M. chilensis to be a subspecies of M. edulis (McDonald et al. 1991), but data obtained from mitochondrial DNA (Hilbish et al. 2000), nuclear genes (Rodríguez-Fariña 2001), and satellite DNAs (present study) indicate that this species is closer to M. galloprovincialis than to M. edulis. These results support the taxonomy of Lamy (1936), who proposed that M. chilensis is a species apart from 
M. edulis and M. galloprovincialis In conclusion, our results support the library hypothesis proposed by Salser et al. (1976), in that the analyzed sequences were present as a single copy/low copy number in the non-Mytilus species and as satellite DNAs in the Mytilus species. These sequences must be analyzed in other bivalve species to investigate the extension of this library.

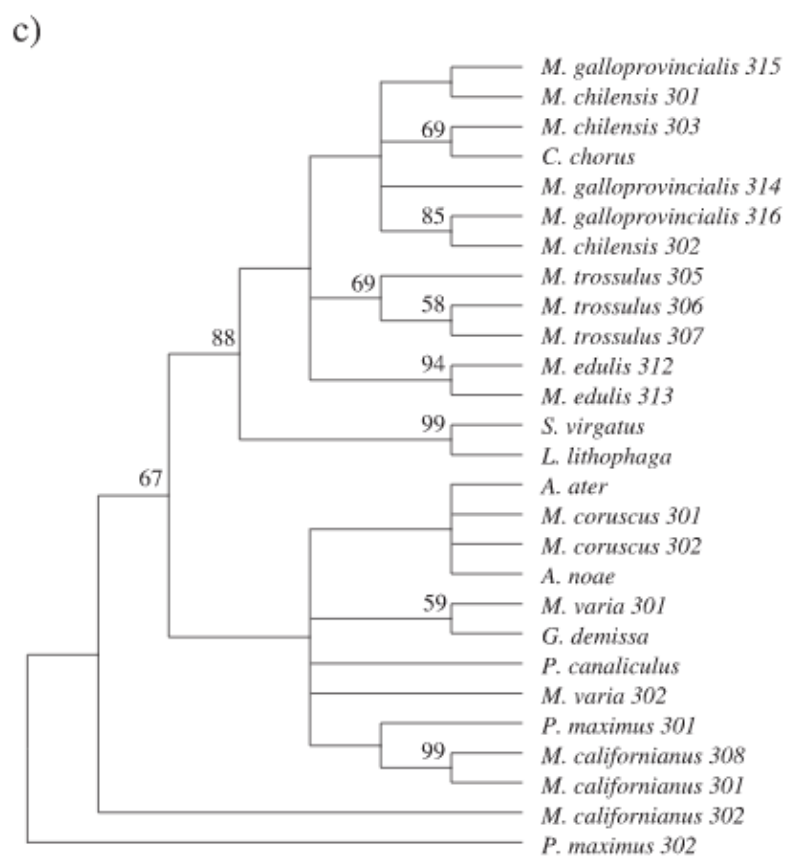

\section{Acknowledgements}

This work was funded by a XUGA grant 10302B97 from the Galician government (Spain) and CICYT (I+D) grant ALI97-0434 from the Spanish government. We are grateful to Dr. J. Ausio (B.C., Canada), Dr. H. Hummel (Holland), Dr. T. Arai (Japan), Dr. Kenchington (N.S., Canada), Dr. G. Román (Galicia, Spain), and ANFACO-CECOPESCA (Galicia, Spain) for kindly providing some of the specimens used in this study, and to Ms. A. Eiroa for revising the English style and grammar.

\section{References}

Adamkewicz, S.L., Harasewych, M.G., Blake, J., Saudek, D., and Bult, C.J. 1997. A molecular phylogeny of the bivalve molluscs. Mol. Biol. Evol. 14: 619-629.

Arnason, U. 1990. Phylogeny of marine mammals - evidence from chromosomes and DNA. In Chromosomes today. Vol X. Edited by K. Fredga, A. Kihlman, and M.D. Bennet. John Wiley \& Sons, New York, pp. 267-278.

Bachmann, L., Venanzetti, F., and Sbordoni, V. 1994. Characterization of a species-specific satellite DNA family of Dolichopoda schiavazzii (Orthoptera, Rhaphidophoridae) cave crickets. J. Mol. Evol. 39: 274-281.

Charlesworth, B., Langley, C.H., and Stephan, W. 1986. The evolution of restricted recombination and the accumulation of repeated DNA sequences. Genetics, 112: 947-962. 
Charlesworth, B., Sniegowski, P., and Stephan, W. 1994. The evolutionary dynamics of repetitive DNA in eukaryotes. Nature, 371: 215-220.

Cox, L.R., Newell, N.D., Branson, C.C., et al. (18 co-authors) 1969. Systematic descriptions. In Treatise on invertebrate paleontology, Part N Mollusca 6, Bivalvia. Edited by R.C. Moore. Geological Society of America and The University Press of Kansas, Lawrence, Kansas, pp. 225-907.

Distel, D.L. 2000. Phylogenetic relationships among Mytilidae (Bivalvia): 18S rRNA data suggest convergence in mytilid plans. Mol. Phyogenet. Evol. 15: 25-33.

Edwards, C.A., and Skibinski, D.O.F. 1987. Genetic variation of mitochondrial DNA in mussel (Mytilus edulis and M. galloprovincialis) populations from southwest England and south Wales. Mar. Biol. 94: $547-556$.

Eirín-López, J.M., González-Tizón, A.M., Martínez, A., and Méndez, J. 2002. Molecular and evolutionary analysis of mussel histone genes (Mytilus spp): possible evidence of an "orphon origin" for H1 histone genes. J. Mol. Evol. 55: 272-283.

Fanning, T.G., Seuanez, H.N., and Forman, L. 1989. Satellite DNA sequences in the neotropical marmoset Callimico goeldii (Primates, Platyrrhini). Chromosoma, 98: 396-401.

Fanning, T.G., Seuanez, H.N., and Forman, L. 1993. Satellite DNA sequences in the New World primate Cebus apella (Platyrrhini, Primates). Chromosoma, 102: 306-311.

Felsenstein, J. 1985. Confidence limits on phylogenies: an approach using bootstrap. Evolution, 39: 783791.

Geiduschek, E.P., and Tocchini-Valentini, G.P. 1988. Transcription by RNA Polymerase III. Annual Rev. Biochem. 57: 873-914.

Geller, J.B., Carlton, J.T., and Powers, D.A. 1993. Interspecific and intrapopulation variation in mitochondrial ribosomal DNA sequences of Mytilus spp. (Bivalvia: Mollusca). Mol. Mar. Biol. Biotechnol. 2: 44-50.

Heath, D.D., and Hilbish, T.J. 1998. Mytilus protamine-like sperm-specific protein genes are multicopy, dispersed and closely associated with hypervariable RFLP regions. Genome, 41: 587596.

Heath, D.D., Rawson, P.D., and Hilbish, T.J. 1995. PCR-based nuclear markers identify alien blue mussel (Mytilus spp.) genotypes on the west coasts of Canada. Can. J. Fish. Aquat. Sci. 52: 2621-2627.

Hilbish, T.J., Mullinax, A., Dolven, S.I., Meyer, R.K., Koehn, R.K., and Rawson, P.D. 2000. Origin of the antitropical distribution pattern in marine mussels (Mytilus spp.): routes and timing of transequatorial migration. Mar. Biol. 136: 69-77.

Ieyama, H., Kameoka, O., Tan, T., and Yamasaki, J. 1994. Chromosomes and nuclear DNA contents of some species in Mytilidae. Venus, 53: 327-331.

Kenchington, E., Landry, D., and Bird, C.J. 1995. Comparison of taxa of the mussel Mytilus (Bivalvia) by analysis of the nuclear small-subunit rRNA gene sequence. Can. J. Fish. Aquat. Sci. 52: 2613-2620.

Kumar, S., Tamura, K., Jakobsen, I.B., and Nei, M. 2001. MEGA2: Molecular Evolutionary Genetics Analysis software. Bioinformatics, 17: 1244-1245. 
Lamy, E. 1936. Révision des Mytilidae vivants du Muséum National d'Histoire Naturelle de Paris. J. Conchy. 80: 66-363.

Li, W.H. 1997. Molecular evolution. Sinauer Associates Inc., Sunderland, Massachusetts.

Martínez-Lage, A., Rodríguez, F., González-Tizón, A., Prats, E., Cornudella, L., and Méndez, J. 2002. Comparative analysis of different satellite DNAs in four Mytilus species. Genome, 45: 922-929.

McDonald, J.H., Seed, R., and Koehn, R.K. 1991. Allozyme and morphometric characters of three species of Mytilus in the northern and southern hemispheres. Mar. Biol. 111: 323-335.

Meštrovi, N., Plohl, M., Mravinac, B., and Ugarkovi, D. 1998. Evolution of satellite DNAs from the genus Palorus - experimental evidence for the "library" hypothesis. Mol. Biol. Evol. 15: 1062-1068.

Miklos, G.L.G. 1985. Localized highly repetitive DNA sequences in vertebrate and invertebrate genomes. In Molecular evolutionary genetics. Edited by R.J. MacIntyre. Plenum Press, New York, pp. 241-321.

Muchmore, M.E., Moy, G.W., Swanon, W.J., and Vacquier, V.D. 1998. Direct sequencing of genomic DNA for characterization of a satellite DNA in five species of eastern Pacific abalone. Mol. Mar. Biol. Biotech. 7: 1-6.

Nijman, I.J., and Lenstra, J.A. 2001. Mutation and recombination in cattle satellite DNA: a feedback model for the evolution of satellite DNA repeats. J. Mol. Evol. 52: 361-371.

Ohshima, N., and Okada, K. 1994. Generality of the tRNA origin of short interspersed repetitive elements (SINEs). Characterization of three different tRNA-derived retroposons in the octopus. J. Mol. Biol. 243: $25-37$.

Ohshima, K., Koishi, R., Matsuo, M., and Okada, N. 1993. Several short interspersed repetitive elements (SINEs) in distant species may have originated from a common ancestral retrovirus: characterization of a squid SINE and a possible mechanism for generation of tRNA-derived retroposons. Proc. Natl. Acad. Sci. USA, 90: 6260-6264.

Rice, E.L., and Bird, C.J. 1990. Relationships among geographically distant populations of Gracilaria verrucosa (Gracilariales, Rhodophyta) and related species. Phycologia, 29: 501-510.

Rodríguez-Fariña, F. 2001. Estudio molecular de secuencias de copia única y de ADN satélite en mejillón. Doctoral Thesis, Universidade da Coruña, Spain.

Salser, W.S., Bowendbrowne, et al. 1976. Investigation of the organization of mammalian chromosomes at the DNA sequence level. Fed. Proc. 35: 23-35.

Singer, M.F. 1982. Highly repeated sequences in mammalian genomes. Int. Rev. Cytol. 76: 67-112.

Steiner, G., and Müller, M. 1996. What can 18S rDNA do for bivalve phylogeny? J. Mol. Evol. 43: 58-70.

Stephan, W. 1989. Tandem-repetitive noncoding DNA: forms and forces. Mol. Biol. Evol. 6: 198-212.

Thompson, J.D., Gibson, T.J., Plewniak, F., Jeanmougin, F., and Higgins, D.G. 1997. The ClustalX windows interface: flexible strategies for multiple sequence alignment aided by quality analysis tools. Nucleic Acids Res. 24: 4876-4882.

Van den Busche, R.S., Baker, R.J., Wichman, H.A., and Hamilton, M.J. 1993. Molecular phylogenetics of Stenodermatini bat genera: congruence of data from nuclear and mitochondrial DNA. Mol. Biol. Evol. 10: 944-959. 
Wijers, E.R., Zijlstra, C., and Lenstra, J.A. 1993. Rapid evolution of horse satellite DNA. Genomics, 18: $113-117$.

Willard, H.F. 1991. Evolution of alpha satellite. Curr. Opin. Gen. Dev. 1: 509-514.

Winnepenninckx, B., Backeljau, T., and DeWachter, R. 1996. Investigation of molluscan phylogeny on the basis of 18S rRNA sequences. Mol. Biol. Evol. 13: 1306-1317. 